\title{
Rola medycyny nuklearnej w diagnostyce chorób układu ruchu.
}

\section{The role of nuclear medicine in the musculoskeletal diseases' diagnosis.}

\author{
Iga Strojna ${ }^{1}$, Witold Cholewiński ${ }^{1}$
}

${ }^{1}$ Katedra i Zakład Elektroradiologii, Uniwersytet Medyczny im. K. Marcinkowskiego w Poznaniu

\section{Streszczenie}

Techniki obrazowe z zakresu medycyny nuklearnej znajdują szerokie zastosowanie w ocenie licznych jednostek chorobowych, w tym - schorzeń układu ruchu. Wśród najczęściej wykorzystywanych metod radioizotopowych, wyróżniamy: scyntygrafię trójfazową (z ang. triple-phase scintigraphy), tomografię emisyjną pojedynczego fotonu ( $\mathrm{z}$ ang. single-photon emission tomography, SPECT) oraz pozytonową tomografię emisyjną/tomografię komputerową (z ang. positron emission tomography/computed tomography, PET/CT).
Abstract the positron emission tomography/computed tomography (PET/CT).
Słowa kluczowe: choroby układu ruchu, medycyna nuklearna, układ ruchu
Keywords: musculoskeletal diseases, nuclear medicine, musculoskeletal system
Adres do korespondencji
Iga Strojna
Katedra i Zakład Elektroradiologii,
Uniwersytet Medyczny im. K. Marcinkowskiego w Poznaniu, Polska
Telefon. +48618850789
e-mail: iga.strojna@onet.pl

Nuclear medicine imaging techniques are widely used in the musculoskeletal disorders diagnosis. The most commonly used are the triple-phase scintigraphy, single-photon emission tomography (SPECT), and 


\section{Wstęp}

Schorzenia układu ruchu (z ang. musculoskeletal disorders, MSD) stanowią liczną grupę chorób mięśni, stawówikości. RozwijającesięMSD mogą byćprzyczyną dolegliwościbólowych orazutrudnionejlokomotoryki, a nawet - niepełnosprawności. MSD to choroby nienowotworowe oraz schorzenia onkologiczne. Do najczęstszych należą: choroba zwyrodnieniowa stawów (z ang. osteoarthritis, OA), reumatoidalne zapalenie stawów (z ang. rheumatoid arthritis, RA), łuszczycowe zapalenie stawów (z ang. psoriatic arthritis, PsA), dna moczanowa, osteoporoza (z ang. osteoporosis, OP) a także zapalenia kości i szpiku (z ang. osteomyelitis, OM) [1-2]. Do najczęstszych nowotworów układu ruchu należą: kostniakomięsak (z ang. osteosarcoma, OS), mięsak Ewinga (z ang. Ewing sarcoma, ES) oraz mięśniakomięsak prążkowanokomórkowy (z ang. rhabdomyosarcoma, RMS). Są to nowotwory złośliwe, występujące najczęściej u dzieci i młodych dorosłych. Wśród starszych chorych dominuje chrzęstniakomięsak (z ang. chondrosarcoma, CS) [3-4].

W diagnostyce MSD wykorzystywane są następujące metody obrazowe: rentgenodiagnostyka konwencjonalna (RTG), tomografia komputerowa (z ang. computed tomography, CT), rezonans magnetyczny ( $\mathrm{z}$ ang. magnetic resonance imaging, MRI), ultrasonografia ( $\mathrm{z}$ ang. ultrasonography, USG) oraz techniki medycyny nuklearnej (z ang. nuclear medicine, NM) [5]. Czułość i swoistość ww. metod obrazowych zależy od rozpoznania, stopnia zaawansowania choroby, lokalizacji zmian patologicznych, a także doboru preparatu radiofarmaceutycznego lub środka cieniującego. Dobór techniki obrazowej oraz protokołu akwizycyjnego jest czynnikiem warunkującym dalsze postępowanie wobec chorego, w tym - dobór odpowiedniej terapii. Obecnie, najczęściej stosowanymi w diagnostyce MSD są techniki NM: scyntygrafia trójfazowa (z ang. triple-phase scintigraphy), tomografia emisyjna pojedynczego fotonu ( $\mathrm{z}$ ang. single-photon emission tomography, SPECT) oraz pozytonowa tomografia emisyjna/tomografia komputerowa (z ang. positron emission tomography/computed tomography, PET/CT).

\section{Cel pracy}

Celem pracy jest przedstawienie roli technik radioizotopowych $\mathrm{w}$ ocenie MSD w oparciu o dostępne piśmiennictwo z ostatnich dziesięciu lat.

\section{Material i metoda}

Treść niniejszej pracy powstała w oparciu o piśmiennictwo naukowe z ostatnich dziesięciu lat, odnoszące się do roli technik medycyny nuklearnej w diagnostyce MSD. Opracowane dane pochodzą z zasobów National Center for Biotechnology Information (NCBI; Stany Zjednoczone Ameryki, 860o Rockville Pike, Bethesda MD, 20894 USA).

\section{Omówienie}

- Pozytonowa tomografia emisyjna (PET)

Obrazowanie z zastosowaniem PET/CT opiera się na wykrywaniu kwantów promieniowania elektromagnetycznego (fotonów anihilacyjnych o energii $511 \mathrm{keV}$ ), emitowanych podczas anihilacji pary pozyton-elektron. Źródłem pozytonów jest otrzymywany sztucznie radioizotop, emitujący pozytony. Metodę PET/CT stosuje się najczęściej w onkologii, jednakże może być stosowana także do oceny chorób nieonkologicznych. W onkologii badanie PET przeprowadzane jest w celu określenia stopnia zaawansowania nowotworu, wykrycia przerzutów odległych, a także monitorowania skuteczności zastosowanego leczenia. Metoda PET/CT pozwala wskazać obszary zapalne, ocenić złamania patologiczne i wskazać obszary zwiększonej aktywności metabolizmu wybranego radiofarmaceutyku [6-7].

W ewaluacji MSD, najszersze zastosowanie znajdują radiofarmaceutyki: ${ }^{18} \mathrm{~F}$-fluorodeoksyglukoza (z ang. ${ }^{18} \mathrm{~F}$-fluorodeoxyglucose, ${ }^{18} \mathrm{~F}$-FDG) oraz fluorek sodu znakowany izotopem ${ }^{18} \mathrm{~F}$ (z ang. ${ }^{18} \mathrm{~F}$-sodium fluorine, $\left.{ }^{18} \mathrm{~F}-\mathrm{NaF}\right) .{ }^{18} \mathrm{~F}-\mathrm{FDG}$ wykorzystywany jest do oceny obszarów podwyższonej utylizacji glukozy: zmian zapalnych, guzów nowotworowych. ${ }^{18} \mathrm{~F}-\mathrm{NaF}$ służy przede wszystkim wskazaniu obszarów podwyższonej 
mineralizacji, w tym: gojących się złamań, a także przerzutów odległych układu kostnego [6,8]. Autorzy [6] sugerują ponadto potencjalną użyteczność metody PET/MRI w diagnostyce MSD.

W ocenie stopnia zaawansowania OS, badanie PET/CT z wykorzystaniem ${ }^{18} \mathrm{~F}-\mathrm{FDG}$ wykazuje blisko 100\% czułość. W przypadku wznowy miejscowej OS, czułość metody sięga 85,7\%, a przy wykrywaniu przerzutów odległych - 95\%. Badanie PET/CT jest równie przydatne w diagnostyce ES. Technika ${ }^{18} \mathrm{~F}-\mathrm{FDG}$ PET/CT pozwala wskazać liczbę, lokalizację i objętość guzów, a także - aktywność metabolizmu glukozy ES. Dane te służą ocenie stopnia zaawansowania choroby i pozwalają ocenić inwazyjność ES [9]. W przypadku chorób reumatoidalnych, badanie ${ }^{18} \mathrm{~F}-\mathrm{FDG}$ PET/CT wykrywa aktywne stany zapalne, charakterystyczne dla artretyzmu. Badanie to może być użyteczne w diagnostyce i monitorowaniu leczenia RA, spondyloartropatii czy PsA [10].

Rola obrazowania PET/MRI w diagnozowaniu MSD jest wciąż badana. Autorzy [11] wykazują, że wykorzystanie techniki PET/MRI może być pomocne w ocenie MSD, zapewniając jednocześnie ograniczenie ekspozycji chorych na promieniowanie jonizujące [11].

\section{- Tomografia emisyjna pojedynczego fotonu (SPECT)}

Najczęściej stosowaną w onkologii metodą oceny układu kostnego jest BS, pozwalająca na skanowanie całej powierzchni ciała chorego w czasie jednej akwizycji. Badanie to cechuje wysoka czułość w wykrywaniu ognisk patologicznych, jednakże niska swoistość (ok. 60\%) w rozróżnianiu guzów łagodnych i przerzutów do kości. Technika SPECT jest metodą obrazowania objętościowego, wykorzystywaną w celu zwiększenia precyzji wykrywania i rozróżniania zmian patologicznych w układzie kostnym. Użycie tej metody obrazowej zapewnia względnie wysoką czułość (87\%) i swoistość (91\%) w określeniu prawdopodobnego charakteru ocenianego ogniska [12]. Ograniczeniem badania SPECT jest długi czas akwizycji (nierzadko: przeszło godzinę) całego układu kostnego, co skutkuje koniecznością określenia lokalizacji zmian podejrzanych przed przystąpieniem do szczegółowej oceny obserwowanego guza (wykrywanego metodą BS lub techniką skanowania radiologicznego). W praktyce klinicznej, najczęściej wykorzystywane jest połączenie technik SPECT i CT, co pozwala na precyzyjne wskazanie granic guza poddawanego ocenie [13].

W obrazowaniu układu kostnego techniką SPECT/CT, najpowszechniej stosowanymi radiofarmaceutykami są dwufosfoniany znakowane izotopem technetu- ${ }^{99}$ metastabilnego (metastabilny - krótkotrwale wzbudzony, z ang. ${ }^{99 m}$ Tc-labelled diphosphonates). Preparat ten, wykorzystywany także w technice BS, podlega wzmożonej utylizacji m.in. w: ogniskach pierwotnych i wtórnych kości, w miejscach, w których doszło do przerwania ciągłości tkanki kostnej (złamania, urazy) lub w obszarach podwyższonej mineralizacji [14-15]. Z uwagi na czas trwania akwizycji (około 15-30 minut) i względnie wysoką dostępność, technika BS pozostaje najczęściej wybieranym narzędziem oceny stopnia zaawansowania i odpowiedzi na leczenie choroby nowotworowej (ocena ognisk wtórnych w układzie kostnym). Uzupełnienie protokołu BS o akwizycję SPECT/CT zwiększa precyzję oceny charakteru badanej zmiany w kości [16].

Autorzy [17] wskazują przydatność techniki SPECT w wykrywaniu RA. Metoda ta, w porównaniu do badania BS, pozwala na wykrycie większej liczby stawów objętych RA lub OA [17]. Badanie SPECT przydatne jest także w wykrywaniu chorób z grupy OM, w których przebiegu dochodzi do zwiększonego ukrwienia i transportu komórek zapalnych do ogniska objętego procesem chorobowym. Prawidłowość ta skutkuje wychwytem radiofarmaceutyku w miejscu infekcji i lokalizacją obszaru stanu zapalnego, co może pozwolić także na rozróżnienie zmiany zapalnej kości i tkanek miękkich [14].

\section{Dyskusja}

MSD to grupa schorzeń stawów, kości i mięśni. Przebiegowi MSD towarzyszą często dolegliwości bólowe i związane z tym trudności w poruszaniu się, co może obniżać jakość życia chorego i prowadzić do chorób układu krążenia, czy też otyłości. Do MSD należą zarówno schorzenia nieonkologiczne (OA, RA), jak i onkologiczne (OS, ES).

W diagnostyce MSD, szerokie zastosowanie znajdują techniki z zakresu NM: BS, SPECT, PET. Najczęściej stosowaną metodą obrazowania jest BS z użyciem dwufosfonianów znakowanych izotopem ${ }^{99 m}$ Tc. Technika ta, z uwagi na wysoką czułość (do 95\%) w ocenie układu kostnego, umożliwia wskazanie obszarów objętych 
procesem chorobowym. Niska swoistość (do 60\%) metody utrudnia jednakże diagnostykę różnicową, m.in. zmian łagodnych i złośliwych w kości $[18,19]$. Poszerzenie postępowania diagnostycznego z użyciem BS o akwizycję SPECT/CT, pozwala na dokładniejszą charakterystykę ewaluowanych zmian, jednakże powoduje dodatkowe narażenie na szkodliwe skutki oddziaływania promieniowania jonizującego (skanowanie CT) [20]. Czas obrazowania całego ciała metodą SPECT/CT jest ponadto wydłużony w porównaniu z BS (około 60 w stosunku do 20 minut BS), co wymusza konieczność wskazania lokalizacji obserwowanej zmiany z użyciem innej metody przed akwizycją SPECT. Technika PET/CT pozwala na diagnostykę takich schorzeń, jak: OS, ES, RA. Najczęściej wykorzystywanym radiofarmaceutykiem w badaniu PET/CT jest ${ }^{18}$ F-FDG, jednakże najwyższą swoistość metody w ocenie układu kostnego cechuje obrazowanie z użyciem radioznacznika ${ }^{18} \mathrm{~F}-\mathrm{NaF}$. ${ }^{18} \mathrm{~F}-\mathrm{FDG}$ ulega akumulacji w obszarach o podwyższonej aktywności metabolizmu glukozy, co utrudnia diagnostykę różnicową zmian łagodnych i złośliwych w kości. ${ }^{18} \mathrm{~F}-\mathrm{NaF}$ ulega natomiast gromadzeniu m.in. w obszarach podwyższonej mineralizacji tkanki kostnej. Autorzy [21] wskazują na użyteczność metody PET/CT w diagnostyce nowotworów tkanek miękkich występujących w obrębie układu mięśniowoszkieletowego [21]. Potencjalnie, użyteczną techniką ewaluacji MSD jest badanie PET/MRI, ograniczające narażenie chorych na szkodliwe skutki oddziaływania promieniowania jonizującego i użyteczne w ocenie tkanek miękkich $[22,23]$. Jednakże, z uwagi na niewystarczającą liczbę doniesień naukowych oraz niską dostępność techniki, wskazania do wykonania badania PET/MR pozostają niejednoznaczne.

\section{Wnioski}

Techniki NM znajdują szerokie zastosowanie w diagnostyce MSD nieonkologicznych jak i onkologicznych. Używane są zarówno do wykrywania MSD, ale również do oceny charakteru, stopnia zaawansowania choroby, a także monitorowania zastosowanego leczenia.

\section{Konflikt interesu / Conflict of interest}

Nie występuje / None

\section{Etyka / Ethics}

Treści przedstawione w artykule są zgodne z zasadami Deklaracji Helsińskiej, dyrektywami EU oraz ujednoliconymi wymaganiami dla czasopism biomedycznych.

\section{Bibliografia}

[1] Lewis R, Gómez Álvarez CB, Rayman M, Lanham-New S, Woolf A, Mobasheri A. Strategies for optimising musculoskeletal health in the 21st century. BMC Musculoskelet Disord. 2019 Apr 11;20(1):164. doi: 10.1186/s12891-019-2510-7. PMID: 30971232; PMCID: PMC6458786.

[2] Briggs AM, Woolf AD, Dreinhöfer K, Homb N, Hoy DG, Kopansky-Giles D, et al. Reducing the global burden of musculoskeletal conditions. Bull World Health Organ. 2018 May 1;96(5):366-368. doi: 10.2471/BLT.17.204891. Epub 2018 Apr 12. PMID: 29875522 ; PMCID: PMC5985424.

[3] Ferguson JL, Turner SP. Bone Cancer: Diagnosis and Treatment Principles. Am Fam Physician. 2018 Aug 15;98(4):205-213. PMID: 30215968.

[4] Arndt CA, Rose PS, Folpe AL, Laack NN. Common musculoskeletal tumors of childhood and adolescence. Mayo Clin Proc. 2012 May;87(5):475-87. doi: 10.1016/j.mayocp.2012.01.015. PMID: 22560526; PMCID: PMC3538469.

[5] Kumar, Y., Hayashi, D. Role of Imaging in Musculoskeletal Care. Curr Phys Med Rehabil Rep 4, 28-36 (2016). https://doi.org/10.1007/s40141-016-0106-9.

[6] Kogan F, Broski SM, Yoon D, Gold GE. Applications of PET-MRI in musculoskeletal disease. J Magn Reson Imaging. 2018 Jul;48(1):27-47. doi: 10.1002/jmri.26183. PMID: 29969193; PMCID: PMC6032526.

[7] Vaquero JJ, Kinahan P. Positron Emission Tomography: Current Challenges and Opportunities for Technological Advances in Clinical and Preclinical Imaging Systems. Annu Rev Biomed Eng. 2015;17:385- 
414. doi: 10.1146/annurev-bioeng-071114-040723. PMID: 26643024; PMCID: PMC5299095.

[8] Yoder JS, Kogan F, Gold GE. Applications of PET-Computed Tomography-Magnetic Resonance in the Management of Benign Musculoskeletal Disorders. PET Clin. 2019 Jan;14(1):1-15. doi: 10.1016/j. cpet.2018.08.001. PMID: 30420212; PMCID: PMC6245663.

[9] Behzadi AH, Raza SI, Carrino JA, Kosmas C, Gholamrezanezhad A, Basques K, et al. Applications of PET/CT and PET/MR Imaging in Primary Bone Malignancies. PET Clin. 2018 Oct;13(4):623-634. doi: 10.1016/j.cpet.2018.05.012. Epub 2018 Aug 17. PMID: 30219192; PMCID: PMC7466825.

[10] Hotta M, Minamimoto R, Kaneko H, Yamashita H. Fluorodeoxyglucose PET/CT of Arthritis in Rheumatic Diseases: A Pictorial Review. Radiographics. 2020 Jan-Feb;40(1):223-240. doi: 10.1148/rg.2020190047. PMID: 31917663 .

[11] Andersen KF, Jensen KE, Loft A. PET/MR Imaging in Musculoskeletal Disorders. PET Clin. 2016 Oct;11(4):453-63. doi: 10.1016/j.cpet.2016.05.007. PMID: 27593249.

[12] O’Sullivan GJ, Carty FL, Cronin CG. Imaging of bone metastasis: An update. World J Radiol. 2015 Aug 28;7(8):202-11. doi: 10.4329/wjr.v7.i8.202. PMID: 26339464; PMCID: PMC4553252.

[13] Choi J, Raghavan M. Diagnostic imaging and image-guided therapy of skeletal metastases. Cancer Control. 2012 Apr;19(2):102-12. doi: 10.1177/107327481201900204. PMID: 22487972.

[14] Love C, Palestro CJ. Nuclear medicine imaging of bone infections. Clin Radiol. 2016 Jul;71(7):632-46. doi: 10.1016/j.crad.2016.01.003. Epub 2016 Feb 17. PMID: 26897336.

[15] Soundararajan R, Naswa N, Sharma P, Karunanithi S, Nazar AH, Das KJ, et al. SPECT-CT for characterization of extraosseous uptake of $99 \mathrm{mTc}-\mathrm{methylene}$ diphosphonate on bone scintigraphy. Diagn Interv Radiol. 2013 Sep-Oct;19(5):405-10. doi: 10.5152/dir.2013.054. PMID: 23748034.

[16] Cook GJ, Azad GK, Goh V. Imaging Bone Metastases in Breast Cancer: Staging and Response Assessment. J Nucl Med. 2016 Feb;57 Suppl 1:27S-33S. doi: 10.2967/jnumed.115.157867. PMID: 26834098.

[17] McQueen FM. Imaging in early rheumatoid arthritis. Best Pract Res Clin Rheumatol. 2013 Aug;27(4):499522. doi: 10.1016/j.berh.2013.09.005. Epub 2013 Oct 4. PMID: 24315051.

[18] Łukaszewski B, Nazar J, Goch M, Łukaszewska M, Stępiński A, Jurczyk MU. Diagnostic methods for detection of bone metastases. Contemp Oncol (Pozn). 2017;21(2):98-103. doi: 10.5114/wo.2017.68617. Epub 2017 Jun 30. PMID: 28947878; PMCID: PMC5611498.

[19] Zając R, Radzińska P, Pietrzak AK, Wiecheć K, Żurawski J, Cholewiński W. Użyteczność metod radioizotopowych w leczeniu przerzutów nowotworowych do układu kostnego - przegląd metod. Letters in Oncology Science 2019 15(4), 126-133. https://doi.org/10.21641/los.15.4.99

[20] Ghosh P. The role of SPECT/CT in skeletal malignancies. Semin Musculoskelet Radiol. 2014 Apr;18(2):17593. doi: 10.1055/s-0034-1371019. Epub 2014 Apr 8. PMID: 24715449.

[21] Katal S, Gholamrezanezhad A, Kessler M, Olyaei M, Jadvar H. PET in the Diagnostic Management of Soft Tissue Sarcomas of Musculoskeletal Origin. PET Clin. 2018 Oct;13(4):609-621. doi: 10.1016/j. cpet.2018.05.011. PMID: 30219191; PMCID: PMC7466822.

[22] Hayashi D, Roemer FW, Guermazi A. Imaging of osteoarthritis-recent research developments and future perspective. Br J Radiol. 2018 May;91(1085):20170349. doi: 10.1259/bjr.20170349. Epub 2018 Jan 19. PMID: 29271229; PMCID: PMC6190779.

[23] Kogan F, Fan AP, Gold GE. Potential of PET-MRI for imaging of non-oncologic musculoskeletal disease. Quant Imaging Med Surg. 2016 Dec;6(6):756-771. doi: 10.21037/qims.2016.12.16. PMID: 28090451; PMCID: PMC5219958. 